\title{
Positivity yield of HIV index testing services from selected healthcare facilities in Ondo State, southwest Nigeria
}

\author{
Emeh, A., *Usman, S. O., Adebanjo, A. M., Ogboghodo, E., Akinbinu, B., Suraju, A., \\ Udechukwu, C., Ale, J., Ariyo, A., Owolagba, F. E., Jolayemi, T., and Okonkwo, P.
}

APIN Public Health Initiatives, Abuja, Nigeria

*Correspondence to: senatorhopsy@yahoo.com

\begin{abstract}
:
Background: Index testing is a voluntary process whereby HIV seropositive clients are counselled and, after obtaining consent, their sexual and needle sharing partners are offered HIV testing services. Index testing has been associated with high HIV positivity yield. The aim of this study is to determine the positivity yield and identify factors influencing the yield from index testing strategy in selected healthcare facilities in Ondo State, southwest Nigeria. Methodology: Six public hospitals in Ondo State with the highest HIV clients currently on treatment were selected. Records of all clients newly diagnosed to be HIV positive at the selected facilities from June 2018 to September 2019, and who had an outcome for index testing services were reviewed. Data were collected using a chart abstraction template from the index testing registers. Information collected included age and gender of the index clients and their partners, method of referral and notification of partners, HIV test results of partners and linkage status of new HIV positive partners. Data analyses were done using the Statistical Package for the Social Sciences (SPSS) software version 24.0. Chi-square was used to test association between variables at a significance level of $p<0.01$.

Results: The records of a total of 904 index clients and their partners were reviewed with partner elicitation ratio of $1: 1$. The mean ages of index clients and their partners were 38.52 \pm 10.96 and $38.98 \pm 10.79$ years respectively, and majority of the index clients (34.6\%) and partners (35.5\%) were in the 35-44 years age group. A total of 548 index clients were females $(60.6 \%)$ while 528 of their partners were males $(58.4 \%)$, indicating predominantly heterosexual $(96.4 \%)$ and few homosexual (lesbian) relationships (3.6\%). One-fifth (20\%) of partners tested positive for HIV and were all $(100 \%)$ linked to antiretroviral therapy (ART). The HIV positivity rate in partners of male index clients $(26.9 \%)$ was significantly higher than in partners of female index clients $(15.5 \%)(p<0.01)$. Partner referral method was mostly through assisted referral (56\%) and most ( $82 \%)$ were contacted by the index clients through phone. Conclusion: Due to its high positivity yield, index testing is a veritable strategy to increase HIV case detection and linkage to ART. Hence, proper deployment of index testing will be critical to improving ART coverage and achieving epidemiological control.
\end{abstract}

Keywords: HIV, client; partner; index testing; ART; southwest Nigeria

Received April 25, 2020; Revised July 8, 2020; Accepted July 9, 2020

Copyright 2021 AJCEM Open Access. This article is licensed and distributed under the terms of the Creative Commons Attrition 4.0 International License <a rel="license" href="http://creativecommons.org/licenses/by/4.0/", which permits unrestricted use, distribution and reproduction in any medium, provided credit is given to the original author(s) and the source. Editor-in-Chief: Prof. S. S. Taiwo

\section{Rendement positif des services de dépistage de l'indice du VIH dans certains établissements de santé de l'État d'Ondo, dans le sud-ouest du Nigéria}

\author{
Emeh, A., *Usman, S. O., Adebanjo, A. M., Ogboghodo, E., Akinbinu, B., Suraju, A., \\ Udechukwu, C., Ale, J., Ariyo, A., Owolagba, F. E., Jolayemi, T., et Okonkwo, P. \\ Initiatives de santé publique APIN, Abuja, Nigéria \\ *Correspondance à: senatorhopsy@yahoo.com
}

\section{Abstrait:}

Contexte: Le test d'indexation est un processus volontaire par lequel les clients séropositifs pour le VIH sont 
conseillés et, après avoir obtenu leur consentement, leurs partenaires sexuels et de partage de seringues se voient offrir des services de dépistage du VIH. Le test d'index a été associé à un rendement élevé de positivité au VIH. Le but de cette étude est de déterminer le rendement de positivité et d'identifier les facteurs influençant le rendement de la stratégie de test d'index dans certains établissements de santé de l'État d'Ondo, dans le sud-ouest du Nigéria. Méthodologie: Six hôpitaux publics de l'État d'Ondo avec les clients VIH les plus élevés actuellement sous traitement ont été sélectionnés. Les dossiers de tous les clients nouvellement diagnostiqués séropositifs dans les établissements sélectionnés de juin 2018 à septembre 2019 et qui ont obtenu un résultat pour les services de test d'index ont été examinés. Les données ont été collectées à l'aide d'un modèle d'abstraction de graphique à partir des registres de test d'index. Les informations recueillies incluaient l'âge et le sexe des clients de l'indice et de leurs partenaires, la méthode d'orientation et de notification des partenaires, les résultats des tests de dépistage du VIH des partenaires et le statut de liaison des nouveaux partenaires séropositifs. Les analyses de données ont été effectuées à l'aide du logiciel Statistical Package for the Social Sciences (SPSS) version 24.0. Le chi carré a été utilisé pour tester I'association entre les variables à un niveau de signification de $p<0,01$.

Résultats: Les dossiers d'un total de 904 clients index et de leurs partenaires ont été examinés avec un ratio de sollicitation des partenaires de 1:1. L'âge moyen des clients de l'indice et de leurs partenaires était de 38,52 $\pm 10,96$ et 38,98 $\pm 10,79$ ans respectivement, et la majorité des clients de l'indice $(34,6 \%)$ et des partenaires (35,5\%) appartenaient au groupe d'âge des 35-44 ans. Un total de 548 clients index étaient des femmes (60,6\%) tandis que 528 de leurs partenaires étaient des hommes $(58,4 \%)$, indiquant principalement des relations hétérosexuelles $(96,4 \%)$ et peu de relations homosexuelles (lesbiennes) $(3,6 \%)$. Un cinquième $(20 \%)$ des partenaires étaient positifs pour le VIH et étaient tous (100\%) liés à un traitement antirétroviral (ART). Le taux de positivité pour le VIH chez les partenaires des clients de sexe masculin $(26,9 \%)$ était significativement plus élevé que chez les partenaires des femmes de sexe féminin $(15,5 \%)(p<0,01)$. La méthode de référence des partenaires se faisait principalement par référence assistée $(56 \%)$ et la plupart $(82 \%)$ étaient contactés par téléphone par les clients indexés. Conclusion: En raison de son rendement élevé de positivité, le test d'indexation est une véritable stratégie pour augmenter la détection des cas de VIH et le lien avec le TAR. Par conséquent, un déploiement approprié des tests d'indexation sera essentiel pour améliorer la couverture des TAR et réaliser le contrôle épidémiologique.

Mots-clés: VIH, client; partenaire; tests d'index; ART; sud-ouest du Nigeria

\section{Introduction:}

Index testing (IT) is a voluntary process where trained health workers, and lay providers, ask people diagnosed with HIV about their sexual partners or drug injecting partners and, with the consent of the HIV-positive client, offer these partners voluntary HIV testing (1). The sexual partners and drug injecting partners of people diagnosed with HIV infection have an increased probability of also being HIV-positive. Index testing services does not always require disclosure to the partner and may be anonymously conducted. These services are an efficient and effective way to diagnose people with HIV, link persons to HIV care, and identify partners in need of HIV prevention services (1). Index testing has been an important public health approach in infectious disease case detection and control for decades. This strategy has also been a part of programs for sexually transmitted infections and tuberculosis but has not previously been routinely implemented for HIV program (2).

Index testing increase uptake of HIV testing services among partners of people with HIV, result in high positivity yield, and increased linkage to treatment and care among partners of people with HIV. Other benefits of index testing include mutual support to access HIV prevention, treatment and care services, improved adherence and retention on treatment, increased support for the prevention of motherto-child transmission and prioritization of effect- tive HIV prevention for serodiscordant couples such as condom use, antiretroviral therapy, and pre-exposure prophylaxis for HIV-negative partners (2). This innovative strategy increases access to HIV testing services for populations currently underserved including adolescent girls and young women, adolescent boys and young men, partners of women tested in antenatal clinics and key populations amongst others.

Index testing ensures that the partners of HIV positive clients benefit from opportunities to learn their HIV status and commence ART if tested HIV positive. Therefore, index testing has a role to play in achieving optimum ART coverage and epidemiological control. Partner referral methods could either be passive referral, where index clients are encouraged to disclose their status and suggest HIV testing to their partner(s) on their own; contract referral, where index clients enter into a contract with the provider to refer their partner(s) to HIV testing within an agreed time period, after that the provider contacts the partner(s) directly and offers HIV testing, while maintaining the anonymity of the index patient; provider referral, where providers directly contact partners of index patients to offer HIV testing; or dual referral where the provider accompanies the index patient when they disclose their status and offers HIV testing to their partner(s) (3).

In five observational studies, assisted partner notification was associated with incr- 
eased uptake of HIV testing services (HTS) among identified partners compared to passive referral (4-7). The proportion of partners of index patients who tested HIV-positive ranged from 20 to $72 \%$ in both passive and assisted arms of the four trials. Among the observational studies, the highest proportion of partners testing HIV positive was $86 \%$. In four studies that reported on couples, between 29 and $40 \%$ were in serodiscordant partnerships (8-11). In Tijuna Mexico, 46 HIV-positive men having sex with men (MSM) and transgender women (TW) were enrolled as index patients and $132 \mathrm{MSM} /$ TW partners were elicited for index testing. Out of the notified partners, 39\% tested for HIV and $28 \%$ of these were newly diagnosed as HIVpositive. Partners who were seen by the index patient more than once in the past 4 months and those who primarily had sex with the index patient in one of their homes were more likely to be notified for index testing (12).

The present study aims to provide further knowledge on the outcomes of index testing efforts in Nigeria. Its specific objectives are to determine the HIV positivity yield from index testing in selected healthcare facilities in Ondo State, southwest Nigeria, and to identify factors associated with higher positivity yield from index testing.

\section{Materials and method:}

\section{Study setting}

This study was conducted in six public healthcare facilities providing index testing services for the highest number of persons living with HIV (PLHIV) in Ondo State, southwest Nigeria from June 2018 to September 2019. The facilities were; State Specialist Hospital Akure, State Specialist Hospital Ikare, State Specialist Hospital Ondo, State Specialist Hospital Okitipupa, Federal Medical Centre Owo, and General Hospital Ore.

\section{Study design, subjects and data collection}

The study is a retrospective review of all newly diagnosed HIV positive clients with an outcome for index testing in the six selected facilities. HIV diagnosis was made following the national HIV serial testing algorithm with rapid test kits. Records of a total of 904 consecutive HIV-positive index clients (with their partners, $n=904$ ) who received index testing services during the period of study were reviewed. Data were retrieved from the index testing registers using a chart abstraction template which contained columns for all relevant information necessary for the study. Omitted information in the register was sought from other program registers and patient care cards.
Information collected included age and gender of the index clients and their partners, method of referral and notification of partners, HIV test results of partners and linkage status of new HIV positive partners. Partner referral methods were; (i) passive referral, where index clients were encouraged to disclose their status and suggest HIV testing to their partner(s) on their own; (ii) contract referral, where index clients entered into a contract with the provider to refer their partner(s) to HIV testing within an agreed time period, after which the provider contacts the partner(s) directly and offers HIV testing, while maintaining anonymity of the index patient; (iii) provider referral, where providers directly contact partners of index patients to offer HIV testing; and (iv) dual referral where the provider accompanies the index patient when they disclose their status and offers HIV testing to their partner(s) (3).

\section{Data entry and analysis}

Collated data were reviewed and checked for completeness. Data entry and analysis were done using the Statistical Package for the Social Sciences (SPSS) software version 24.0. Chi-square was used to test association between different groups at a significance level of $p<0.01$.

\section{Ethical considerations}

Ethical approval to conduct the study was obtained from the review team of the APIN Public Health Initiative, Akure, Ondo State. Confidentiality was maintained by ensuring that names, hospital numbers and contact details of clients were not captured in the chart abstraction tool.

\section{Results:}

The records of 904 index HIV clients and 904 partners recruited with partner elicitation ratio of $1: 1$, were reviewed for the study in the 6 selected hospitals in Ondo State, southwest Nigeria. The State Specialist Hospital Okitipupa had the highest number of clients participating in the study with $184(20.4 \%)$ while Federal Medical Centre, Owo had the lowest number of 105 (11.6\%) (Table 1).

Table 1: Frequency distribution of HIV-positive index clients from six selected hospitals in Ondo State, southwest Nigeria

\begin{tabular}{ccc}
\hline Hospital & \multicolumn{2}{c}{ Index client } \\
\hline & $\begin{array}{c}\text { Frequency } \\
(\mathrm{n}=904)\end{array}$ & $\begin{array}{c}\text { Percent } \\
(\%)\end{array}$ \\
Federal Medical Centre, Owo & 105 & 11.6 \\
Ore General Hospital & 164 & 18.1 \\
State Specialist Hospital, Akure & 154 & 17.0 \\
State Specialist Hospital, Ikare & 155 & 17.1 \\
State Specialist Hospital, Okitipupa & 184 & 20.4 \\
State Specialist Hospital, Ondo & 142 & 15.7 \\
\hline
\end{tabular}


The mean age of the index clients was $38.52 \pm 10.96$ years, while that of the partners was $38.98 \pm 10.79$ years, and majority of the index clients $(34.6 \%)$ and partners $(35.5 \%)$ were in the 35-44 years age group (Table 2). Five hundred and forty-eight (548) of the index clients were females $(60.6 \%)$, while 528 of their partners were males $(58.4 \%)$ indicating predominantly heterosexual $(96.4 \%, n=528)$ and few homosexual (lesbian) relationships $(3.6 \%, n=$ 20).

The HIV positivity rate among partners of index clients was 20\% (181/904), and they were all initiated on ART ( $100 \%$ linkage). The HIV results of both male and female partners were not significantly associated with age group $(p>0.05)$ but the HIV positivity rate of $28.7 \%$ $(108 / 376)$ in the female partners was significantly higher than $13.8 \%(73 / 528)$ in the male partners $(p<0.01)$ (Table 3$)$. Similarly, the HIV positivity rate of $26.9 \%(96 / 356)$ in partners of male clients (who were all females) was significantly higher than the rate of $15.5 \%$ $(85 / 548)$ among partners of female index clients who were mostly but not all males $(p<0.01)$ (Table 4 ). Most $(56.2 \%)$ of the partners were notified using the assisted/provider referral method, and only one client had the dual referral method while none used the contract referral method.

Table 2: Age group and gender distribution of index HIV-positive index clients and partners from six selected hospitals, Ondo State, southwest Nigeria

\begin{tabular}{|c|c|c|c|c|c|c|}
\hline \multirow{2}{*}{$\begin{array}{l}\text { Age group } \\
\text { (years) }\end{array}$} & \multicolumn{3}{|c|}{ Index clients } & \multicolumn{3}{|c|}{ Partners } \\
\hline & Male & Female & Total (\%) & Male & Female & Total (\%) \\
\hline$<15$ & 2 & 2 & $4(0.4)$ & 0 & 1 & $1(0.1)$ \\
\hline $15-24$ & 11 & 55 & $66(7.3)$ & 14 & 30 & $44(4.9)$ \\
\hline $25-34$ & 74 & 191 & $265(29.4)$ & 138 & 146 & $284(31.4)$ \\
\hline $35-44$ & 119 & 194 & $313(34.6)$ & 189 & 132 & $321(35.5)$ \\
\hline $45-54$ & 100 & 76 & $176(19.5)$ & 119 & 53 & $172(19.0)$ \\
\hline $55-64$ & 33 & 25 & $58(6.4)$ & 46 & 12 & $58(6.4)$ \\
\hline$\geq 65$ & 17 & 5 & $22(2.4)$ & 22 & 2 & $24(2.7)$ \\
\hline Total & $356(39.4)$ & $548(60.6)$ & $904(100)$ & $528(58.4)$ & $376(41.6)$ & $904(100)$ \\
\hline $\begin{array}{c}\text { Mean age } \\
\text { (years) }\end{array}$ & & & $38.52 \pm 10.96$ & & & $38.98 \pm 10.79$ \\
\hline
\end{tabular}

Table 3: HIV status of partners in relation to age group and gender in selected hospitals, Ondo State, Southwest Nigeria

\begin{tabular}{|c|c|c|c|c|c|c|}
\hline \multirow{3}{*}{$\begin{array}{c}\text { Age group } \\
\text { (years) }\end{array}$} & \multicolumn{6}{|c|}{ Partner } \\
\hline & \multicolumn{2}{|c|}{ Male } & \multicolumn{2}{|c|}{ Female } & \multicolumn{2}{|c|}{ Total } \\
\hline & No tested & $\begin{array}{c}\text { No positive for } \\
\operatorname{HIV}(\%)\end{array}$ & No tested & $\begin{array}{c}\text { No positive for } \\
\operatorname{HIV}(\%)\end{array}$ & No tested & $\begin{array}{c}\text { No positive for } \\
\text { HIV }(\%)\end{array}$ \\
\hline$<15$ & 0 & 0 & 1 & $1(100)$ & 1 & $1(100)$ \\
\hline $15-24$ & 14 & $3(21.4)$ & 30 & $13(43.3)$ & 44 & $16(36.4)$ \\
\hline $25-34$ & 138 & $14(10.1)$ & 146 & $37(25.3)$ & 284 & 51 (17.9) \\
\hline $35-44$ & 189 & $26(13.8)$ & 132 & $36(27.3)$ & 321 & $62(19.3)$ \\
\hline $45-54$ & 119 & $22(18.5)$ & 53 & $14(26.4)$ & 172 & 36 (20.9) \\
\hline $55-64$ & 46 & $5(10.9)$ & 12 & $6(50.0)$ & 58 & $11(18.9)$ \\
\hline$>65$ & 22 & $3(13.6)$ & 2 & $1(50.0)$ & 24 & $6(25.0)$ \\
\hline Total & 528 & *73 (13.8) & 376 & *108 (28.7) & 904 & $181(20)$ \\
\hline
\end{tabular}

Table 4: HIV status of partners of index clients in relation to age group in selected hospitals, Ondo State, Southwest Nigeria

\begin{tabular}{|c|c|c|c|c|c|c|}
\hline $\begin{array}{l}\text { Age group } \\
\text { (years) }\end{array}$ & $\begin{array}{l}\text { No of partners of } \\
\text { male index client }\end{array}$ & $\begin{array}{c}\text { No positive for } \\
\text { HIV (\%) }\end{array}$ & $\begin{array}{l}\text { No of partners of } \\
\text { female index client }\end{array}$ & $\begin{array}{c}\text { No positive for } \\
\text { HIV (\%) }\end{array}$ & $\begin{array}{l}\text { Total no of } \\
\text { partners of } \\
\text { index client }\end{array}$ & $\begin{array}{l}\text { Total no } \\
\text { positive for } \\
\text { HIV (\%) }\end{array}$ \\
\hline$<15$ & 1 & 0 & 0 & 0 & 1 & 0 \\
\hline $15-24$ & 30 & $10(33.3)$ & 14 & $2(14.3)$ & 44 & $12(27.3)$ \\
\hline $25-34$ & 146 & 32 (21.9) & 138 & $18(13.0)$ & 284 & $50(17.6)$ \\
\hline $35-44$ & 132 & $36(27.3)$ & 189 & $27(14.3)$ & 321 & $63(19.6)$ \\
\hline $45-54$ & 53 & $11(20.8)$ & 119 & 27 (22.7) & 172 & $38(22.1)$ \\
\hline $55-64$ & 12 & $6(50.0)$ & 46 & $7(15.2)$ & 58 & $13(22.4)$ \\
\hline$>65$ & 2 & $1(50.0)$ & 22 & $4(18.2)$ & 24 & $5(20.8)$ \\
\hline Total & 356 & *96 (26.9) & 548 & $* 85(15.5)$ & 904 & $181(20)$ \\
\hline
\end{tabular}


Over $80 \%$ of the partners were contacted via index client by phone, and only about $1 \%$ by the provider in person (Table 5 ). There were no significant association of partner HIV test results with partner notification methods $(p=0.84)$ or with partner contact method $(p=0.77)$.

Table 5: HIV status of partners in relation to partner referral and client contact methods in selected hospitals, Ondo State, southwest Nigeria

\begin{tabular}{|c|c|c|c|c|}
\hline \multirow{2}{*}{$\begin{array}{l}\text { Partner referral } \\
\text { method }\end{array}$} & \multicolumn{2}{|c|}{ HIV test result } & \multirow[t]{2}{*}{ Total } & \multirow{2}{*}{$\begin{array}{c}p \\
\text { value }\end{array}$} \\
\hline & Negative & Positive & & \\
\hline Dual Referral & 1 & 0 & 1 & 0.84 \\
\hline Passive/Client Referral & 314 & 81 & 395 & \\
\hline Provider Referral & 408 & 100 & 508 & \\
\hline Total & 723 & 181 & 904 & \\
\hline \multicolumn{5}{|l|}{$\begin{array}{l}\text { Partner contact } \\
\text { method }\end{array}$} \\
\hline Index client by phone & 591 & 151 & 742 & 0.77 \\
\hline Index client in person & 97 & 20 & 117 & \\
\hline Provider by phone & 25 & 8 & 33 & \\
\hline Provider in person & 10 & 2 & 12 & \\
\hline Total & 723 & 181 & 904 & \\
\hline
\end{tabular}

\section{Discussion:}

This study examined the outcome of index testing (IT) services in Ondo State, south western Nigeria. Six public hospitals with the highest PLHIV clients on treatment were studied. The hospitals were from different locations covering the three senatorial districts of the state. The facilities from the southern part of the state had more participants with $20.4 \%$ from State Specialist Hospital Okitipupa and $18.1 \%$ from Ore General Hospital, compared with those from the more northern zones of the state: State Specialist Hospital Ikare (17.1\%) and Owo (11.6\%).

The mean age of the index clients was $38.52 \pm 10.96$ years, and about $0.5 \%$ of them were $<15$ years of age. Majority $(34.6 \%)$ of the clients were in the 35-44 years group, with $75.4 \%$ being in $25-49$ years, and $16.9 \%$ above 50 years. This is similar to the findings in north central Nigeria where no client in the study was $<15$ years with majority of the clients between $25-49$ years $(69.5 \%)$, while $17.1 \%$ were above 50 years of age (13). These findings may be due to higher prevalence of HIV infection among the adult population, and challenges associated with access to IT services among adolescents.

The gender distribution of the index clients in this study shows $60.6 \%$ females and $39.4 \%$ males, which is the reverse of the findings in northcentral Nigeria where $60 \%$ of the index clients were males and $40 \%$ females (13). This may suggest male HIV dominance in the northern parts of Nigeria, which is the reverse in the southern parts. It may also indicate the health seeking behavior of women in the southwest who may be more proactive and willing to access index testing services. However, the fact that $60.6 \%$ of the HIVpositive index clients were females while $58.4 \%$ of their partners were males indicates predominantly heterosexual $(96.4 \%)$ relationship with few homosexual (lesbian) relationships (3.6\%).

The distribution of referral methods showed $56 \%$ provider referral and $44 \%$ client referral. This is similar to the findings from northcentral Nigeria which showed $68.5 \%$ provider referral and $31.5 \%$ client referral. This underscores the effectiveness of the provider referral method in increasing uptake of index testing services. Also, more than $80 \%$ of partners were contacted via index clients by phone. The HIV positivity rate for this study was $20 \%$ and all identified HIV positive partners were linked to ART treatment (100\% linkage). The linkage rate in our study is better than that reported from a study in Lesotho where $92 \%$ of clients were linked to ART (14). In northcentral Nigeria, the linkage rate was also $92 \%$ but there was a higher HIV positivity rate of $51 \%$. This may be due to the higher HIV prevalence in northcentral compared to southwest Nigeria.

The only factor associated with HIV positivity rate in the partners was gender, with significantly higher rate in female $(28.7 \%)$ than male partners $(13.8 \%)(p<0.01)$, but there was no association with age group $(p>0.05)$. The HIV positivity rate in partners of male index clients who were all females (26.9\%) was also significantly higher than the HIV positivity rate in partners of female index clients who were mostly but not all males $(15.5 \%)(p<0.01)$. This implies that male HIV positive clients are more likely to infect their female partners than female HIV positive clients infect their male partners. This may be due to the differences in the anatomy of the male and female sexual organs, which present higher likelihood of HIV transmission from male to female than vice versa.

\section{Conclusion:}

This study reports $20 \%$ HIV positivity yield among partners of clients who accessed HIV index testing services in selected healthcare facilities in Ondo State, southwest Nigeria, with $100 \%$ linkage of all identified HIV-positive partners. The positivity rate among the partners of male index clients was significantly higher than the positivity rate among partners of the female index clients. Due to the high positivity yield among partners of the index clients in this study, index testing proved to be a veritable 
strategy to increase HIV case detection and linkage to ART. Hence, proper deployment of index testing will be critical to improving ART coverage and achieving epidemiological control.

\section{References:}

1. Katz, D. A., Wong, V. J., Medley, A. M., et al. The power of partners: Experiences from implementing and scaling-up HIV partner notification and index testing services. J Int AIDS Soc. 2019; 22 (S3): e25314

2. World Health Organization (WHO). WHO guidelines on HIV self-testing and partner notification: supplement to consolidated guidelines on HIV testing services: World Health Organization, 2016. http://www.who.int/hiv/topics/vct/en/

3. Johnson, C., Kennedy, C. E., Fonner, V. A., and Siegfried, N. Assisted HIV partner notification services: a systematic review and metaanalysis. AIDS. 2017; 31:1867-1876.

4. Myers, R., Feldacker, C., Cesar, F., et al. Acceptability and effectiveness of assisted HIV partner services in Mozambique: results from a pilot program in a public, urban clinic. Sex Transm Dis 2016; 43: $690-695$

5. Henley, C., Forgwei, G., Welty, T., et al. Scale-up and case-finding effectiveness of and HIV partner services program in Cameroon: an innovative HIV prevention intervention for developing countries Sex Transm Dis. 2013; 40: 909 - 914.

6. Valle, S. M., De Olalla, P. G., Molas, E., et al. Acceptability and effectiveness of two partners' notification strategies of new HIV cases. Int J STD AIDS. 2015; 26: 102 - 103.

7. Udeagu, C. C., Shah D., Shepard, C. W., Bocour, A., Guiterrez, R., and Begier, E. M. Impact of a New
York City Health Department initiative to expand HIV partner services outside STD clinics. Publ HIth Rep. 2012; 127: 107 - 114.

8. Brown, L. B., Miller, W. C., Kamanga, G., et al. HIV partner notification is effective and feasible in sub-Saharan Africa: opportunities for HIV treatment and prevention. J Acquir Immune Defic Syndr. 2011; 56: 437 - 442.

9. Landis, S. E., Schoenbach, V. J., Weber, D. J., et al. Results of a randomized trial of partner notification in cases of HIV infection in North Carolina. N Engl J Med. 1992; 326: 101 - 106.

10. Rosenberg, N. E., Mtande, T. K., Saidi, F., et al. Recruiting male partners for couple HIV testing and counselling in Malawi's option B+ programme: an unblinded randomized controlled trial. Lancet HIV 2015; 2: e483-e491.

11. Cherutich, P., Golden, M. R., Wamuti, B., et al. Assisted partner services for HIV in Kenya: a cluster randomized controlled trial. Lancet HIV. 2017; 4: e74-e82.

12. Semple, S. J., Pines, H. A., Strathdee, S. A., Vera, A. H., Rangel, G., Magis-Rodriguez, C., and Patterson, T. L. Upatke of a partner notification model for HIV among men and transgender women in Tijuana, Mexico. AIDS \& Behaviour. 2017; 1-14.

13. Katibi, M., Adegboye, A., Adedoyin, A., Yunusa, F., Kayode, G., Bello, M., and Dakum, P. Effect of clients Strategic Index Case Testing on communitybased detection of HIV infections (STRICT study). Int J Infect Dis. 2017; 74: 54-60.

14. Jubilee, M., Park, F. J., Chipango, K., Pule, K., Machinda, A., and Taruberekera, N. HIV index testing to improve HIV positivity rate and linkage to care and treatment of sexual partners, adolescents and children of PLHIV in Lesotho. PLoS One. 2019; 14 (3): 00212762.

https://doi.org/10.1371/journal.pone.0212762. 